IZA DP No. 6801

State Merit-based Financial Aid Programs and College Attainment

David L. Sjoquist

John V. Winters

August 2012

Forschungsinstitut zur Zukunft der Arbeit Institute for the Study of Labor 


\title{
State Merit-based Financial Aid Programs and College Attainment
}

\author{
David L. Sjoquist \\ Georgia State University \\ John V. Winters \\ University of Cincinnati \\ and IZA
}

\section{Discussion Paper No. 6801 \\ August 2012}

IZA
P.O. Box 7240
53072 Bonn
Germany

\author{
Phone: +49-228-3894-0 \\ Fax: +49-228-3894-180 \\ E-mail: iza@iza.org
}

\begin{abstract}
Any opinions expressed here are those of the author(s) and not those of IZA. Research published in this series may include views on policy, but the institute itself takes no institutional policy positions.

The Institute for the Study of Labor (IZA) in Bonn is a local and virtual international research center and a place of communication between science, politics and business. IZA is an independent nonprofit organization supported by Deutsche Post Foundation. The center is associated with the University of Bonn and offers a stimulating research environment through its international network, workshops and conferences, data service, project support, research visits and doctoral program. IZA engages in (i) original and internationally competitive research in all fields of labor economics, (ii) development of policy concepts, and (iii) dissemination of research results and concepts to the interested public.
\end{abstract}

IZA Discussion Papers often represent preliminary work and are circulated to encourage discussion. Citation of such a paper should account for its provisional character. A revised version may be available directly from the author. 
IZA Discussion Paper No. 6801

August 2012

\section{ABSTRACT}

\section{State Merit-based Financial Aid Programs and College Attainment ${ }^{*}$}

We examine the effects of recently adopted state merit-based financial aid programs on college attendance and degree completion. Our primary analysis uses microdata from the 2000 Census and 2001-2010 American Community Survey to estimate the effects of merit programs on educational outcomes for 25 merit aid adopting states. We also utilize administrative data for the University System of Georgia to look more in depth at the effects of the HOPE Scholarship on degree completion in Georgia. We find strong consistent evidence that state merit aid programs have no meaningfully positive effect on college completion. Coefficient estimates for our preferred specifications are small and statistically insignificant. State merit aid programs do not appear to increase the percentage of young people with a college education.

JEL Classification: H75, I23, J24

Keywords: merit aid, HOPE, college attainment, degree completion, higher education

Corresponding author:

John V. Winters

University of Cincinnati

Department of Economics

PO Box 210371

Cincinnati, $\mathrm{OH} 45221-0371$

USA

E-mail:winterjh@uc.edu

\footnotetext{
* We thank Rob Watts, Lakshmi Pandey, Charles Zachary and Nancy Snyder for their help. Some of the data used in this article are proprietary and cannot be made publicly available.
} 


\section{Introduction}

College graduation rates have become a national concern and increasing the completion rate is now a national policy target (Resmovits 2012). The 6-year graduation rate for students seeking a bachelor degree was 58.3 percent for the 2004 freshmen cohort, up from 55.4 percent for the 1996 cohort (National Center for Education Statistics 2012). ${ }^{1}$ The interest in increasing the college completion rate and our lack of understanding of what matters has spurred research that attempts to identify causal factors that drive completion or attrition rates; see Melguizo (2011) for a review of this literature. While we do not fully understand what policies improve the attainment rate (Dynarski 2002), one factor that has been investigated is financial aid. Financial aid is expected to increase college completion rates because it lowers the costs of college for students and their families. Financial aid also reduces the need to work while in school, thereby allowing more time for course work, which is expected to increase college performance and perhaps college completion. Goldrick-Rab, Harris, and Trostel (2009) provide an extensive review of the literature of the effects of student aid and note the lack of research that measures causal effects of financial aid.

Increasingly, states have turned to merit-based aid programs, one objective of which is to increase college completion rates. We identified 25 states that implemented a merit-based student aid program between 1991 and 2004 (see Table 1), although the characteristics of these programs differ substantially. ${ }^{2}$ After reviewing the details of all of these programs, we identified 9 programs as being of relatively more significant as measured by the eligibility criteria, the number of students in the program, and the size of the award.

\footnotetext{
${ }^{1}$ Scott-Clayton (2011) calculates a much smaller graduation rate.

2 There are discrepancies in how various authors classify scholarship programs. We used various sources to develop our list; see the sources listed in Table 1.
} 
While merit-based aid could improve college performance, it is not clear whether merit aid will increase the probability of graduating, or graduating within 4 years. For example, Cornwell, Lee, and Mustard (2005) find that HOPE students at the University of Georgia reduced course taking, presumably to be able to spend more time on their courses or to delay losing HOPE. ${ }^{3}$ The requirement that a student maintain a minimum college GPA to retain eligibility provides an incentive to meet this performance standard. But that does not necessarily translate into a higher probability of graduating, or graduating within 4 years. Some merit aid programs require students to enroll full time or limit the number of semesters that a student can be eligible. These requirements do provide an incentive to graduate sooner, however they do not provide a direct incentive to actually graduate. While authors such as Titus (2006) find that financial aid positively affects student performance, scholarships provided to high quality meriteligible students may have no marginal effect on their completion rates if they were very likely to graduate anyway. ${ }^{4}$ Furthermore, fairly stringent renewal requirements cause many marginal recipients to lose merit scholarships after their first or second year of college, limiting the effects on their graduation rates. Some students may be enticed by a merit scholarship to enroll in college but drop out after losing the scholarship.

Research on the effects of merit-based aid on college completion rates is quite limited. ${ }^{5}$

The five papers we identified consider merit-based student aid programs in just four states.

\footnotetext{
${ }^{3}$ The eligibility decision is first made after 30 credit hours are completed, so a student could take 29 credit hours during the first two semesters and then another 15 before the GPA is calculated.

${ }^{4}$ Merit aid programs have also been found to alter the composition of the student body (Dynarski 2004; and Cornwell, Mustard and Sridhar 2006). As a result, a merit aid program could increase the graduation rate at in-state institutions if the program attracted additional high quality students who are more likely to graduate, or reduce the graduation rate if marginal (but still merit aid eligible) students enroll in more demanding public colleges. Our interest, however, is in whether merit programs affect the likelihood an individual graduates from college and not in where they graduate from college.

${ }^{5}$ There is, however, a more developed literature estimating the effects of state merit aid programs on college enrollment including Dynarski (2000, 2004); Cornwell et al. (2006); Singell, Waddell and Curs (2006); Goodman (2008); Orsuwan and Heck (2009); Farrell and Kienzl, (2009); Zhang and Ness (2010); Winters (2012); and Hawley
} 
Three of these find positive and statistically significant effects, but the other two do not. Two of the papers rely on 2000 Census data to measure the effect of the merit aid programs in Arkansas and Georgia (Dynarski 2008 and Sjoquist and Winters 2012a) and three use state agency data to explore the effects of programs in Georgia (Henry, Rubenstein, and Bugler (HRB) 2004), West Virginia (Scott-Clayton 2011), and Tennessee (Bruce and Carruthers 2011). Dynarski finds a positive and statistically significant effect on the graduation rate, while Sjoquist and Winters do not. HRB and Scott-Clayton find a positive effect while Bruce and Carruthers find no effect. In this paper we first employ an approach similar to that used by Dynarski (2008) and Sjoquist and Winters (2012a) but consider all 25 states that we identified as having adopted merit-based aid programs between 1991 and 2004. Our second approach uses agency data for Georgia to revisit HRB's findings and to contrast the results for Georgia with those for West Virginia and Tennessee. Our second approach uses a cohort analysis similar to Scott-Clayton (2011) and Bruce and Carruthers (2011).

Dynarski (2008) treats the adoption of merit aid programs as natural experiments. Her treatment group consists of students who finished high school in Arkansas and Georgia after the programs were adopted, while the comparison group consists of students in states that did not have merit aid programs. Since she does not know who received merit aid, she measures treatment by whether the student would have been exposed to a merit-based aid program while in high school. She uses the 1\% PUMS file from the 2000 Census of Population and finds that the merit-based aid programs had a positive and statistically significant effect on college degree completion of about three percentage points. Sjoquist and Winters (2012a) revisited Dynarski (2008). Employing the same procedures as Dynarski but using the 5\% PUMS they obtain much

and Rork (2012). This literature typically finds a significantly positive effect on the probability of attending college in-state but inconsistent effects on the overall probability of attending college. 
smaller coefficients. Furthermore, using more appropriate inference procedures for clustering, coefficient estimates for both the 1\% and 5\% PUMS are no longer statistically significant.

HRB (2004) explore the effect of Georgia's HOPE program on several academic outcomes, including graduation. Their treatment group consisted of 1,915 HOPE recipients who graduated high school in 1995 and whose overall high school GPAs were close to 3.0. The 1,915 HOPE recipients were matched with a group of non-HOPE recipients who had the same core course GPA and who made the same initial choice of type of higher education institution (research universities; regional universities; 4-year colleges; 2-year colleges). ${ }^{6}$ HRB estimate separate logistic regressions for students at 2-year and 4-year colleges, where the dependent variable is whether the student accumulated sufficient credit hours to graduate between 1995 and fall of 1999. They find that the odds of graduating within four years from a 2-year college is almost twice as high for HOPE recipients, while it is 72 percent greater at 4-year colleges.

Scott-Clayton (2011) uses student-level data to explore the effect of West Virginia's PROMISE program on several academic outcomes, including graduation. Eligibility for the PROMISE program requires a 3.0 high school GPA both overall and for core courses as well as at least a 21 on the ACT (or 1000 on the SAT). Students must maintain a 3.0 GPA in college and take a full course load to remain eligible. She has data on four cohorts of students entering a public college in West Virginia between fall 2000 and fall 2003, and is able to track the students for 5 years post-matriculation. Scott-Clayton uses two empirical approaches, a fuzzy regression discontinuity design using ACT test score as the basis for the discontinuity, and a preand post-PROMISE cohort analysis. For the regression discontinuity design she finds that

\footnotetext{
${ }^{6}$ HOPE eligibility at that time was determined by a student's overall high school GPA. However, a student GPA for core courses was also calculated.
} 
PROMISE increased the 4-year graduation rate by 9.4 percentage points and the 5-year rate by 4.5 percentage points. The cohort analysis results in somewhat smaller effects.

Bruce and Carruthers (2011) use student-level data to explore the effect of Tennessee's HOPE Scholarship program on several academic outcomes, including graduation. Eligibility for the Tennessee aid program requires an overall high school GPA of 3.0 or ACT score of 21 or more (or a 980 SAT score or higher). Students must maintain a 2.75 college GPA after 24 and 48 attempted hours and 3.0 after 72 and 96 attempted hours. They have four cohorts (20052008) of students who enrolled in a Tennessee public four-year college or university, and are able to track students through the 2008-09 school year. Thus, they can determine the four-year graduation rate for just one cohort. Bruce and Carruthers use two empirical approaches, a fuzzy regression discontinuity design and a difference-in-difference approach. For the RD design, they use first time ACT score as an instrument to estimate the probability of obtaining HOPE Scholarship. For the difference-in-difference model they use data for all students entering in 2002-03, i.e. before HOPE, and 2005-06 through 2008-09. For both approaches they find that HOPE had no effect on the probability of graduating within 4 years.

As noted above we utilize two different approaches to examine the effects of state meritbased aid programs on the probability of college completion. Our first approach follows Dynarski (2008) and Sjoquist and Winters (2012a) [jointly referenced as DSW]. There are several limitations with the analyses in DSW. First, having only two states with policy changes resulted in relatively noisy estimates, which partially explains the observed differences in the measured effect when using the 1\% PUMS versus the 5\% PUMS. Additionally, Arkansas' program had a significant income cap for eligibility that limited the number of recipients and the potential effects of the program. Georgia also had income caps during the first two years but 
they were much less restrictive and were eliminated in 1995. However, because the Georgia HOPE Scholarship began in 1993 and DSW only use data from the 2000 census, only four age cohorts in Georgia were exposed to the treatment: persons ages 22-25 as of April 1, 2000. The full effects of HOPE, therefore, may not have had time to manifest themselves for Georgia because many persons ages 22-25 are still in college. Thus DSW provided relatively weak tests.

In this paper we combine the 2000 Census with the 2001-2010 American Community Survey, which allows us to estimate treatment effects for all 25 states with merit-based aid programs compared to just the two states considered by DSW. However, as noted above, some of these programs are stronger than others, and thus our preferred specification estimates merit effects for the 9 states that we identify as having strong merit aid programs. The longer data series also allows us to examine effects at older ages. Our primary sample examines the effects of state merit programs on education outcomes of persons ages 24-30, although we also consider ages 22-23 in an attempt to measure the effect on the four-year graduation rate. We believe that examining many different treatment states and many different birth cohorts makes our analysis a considerable improvement over DSW. Our approach allows us to estimate merit effects much more precisely than DSW and helps resolve the current uncertainty over the effects of state merit aid programs on educational outcomes. Previewing the results using the Census/ACS we find strong robust evidence that state merit aid programs had no meaningful effect on the higher education outcomes of young people in their states.

Our second approach uses administrative data for the University System of Georgia (USG) similar to data used by HRB and employs a cohort analysis similar to that used by ScottClayton (2011). We use student records for two pre- and two post-HOPE cohorts of first time USG freshmen to conduct a pre- and post-HOPE cohort analysis. Controlling for sex, race, 
ethnicity, high school attended and SAT scores, we find no significant difference in degree completion between the pre- and post-HOPE cohorts. Our results using USG data, therefore, reinforce the results using Census/ACS data, but are contrary to the findings of HRB.

We believe our approach is an improvement over HRB's. While HOPE recipients in HRB have an overall GPA close to 3.0, HRB do not observe the overall GPA for non-recipients and do not know how close their overall GPAs are to 3.0. While HRB argue that having equal core GPAs makes the students of similar quality, in fact the mean SAT score for non-recipients is 47 points lower, and half of non-recipients are required to take remedial course work but only 34 percent of recipients are. This suggests that the two groups have different academic ability.

\section{Empirical Framework for Census/ACS Analysis}

\section{Data}

We first use public use microdata samples (PUMS) from the 2000 decennial census long form questionnaire and 2001-2010 American Community Survey (ACS) available at IPUMS (Ruggles et al. 2010). For 2000 we combine the 1\% and 5\% PUMS, which are files released separately and include one percent and five percent of the U.S. population. Sjoquist and Winters (2012a) find non-trivial differences in education levels in Arkansas and Georgia between the 1\% and 5\% PUMS for 2000, so we combine the two instead of using only one. However, the results to follow are robust to using only the 1\% or only the 5\% PUMS for 2000 and are robust to excluding the year 2000 data from the analysis. The census long form was discontinued after 2000 and replaced with the annually conducted American Community Survey. ${ }^{7}$ For years 20012004, the ACS is a roughly 0.4 percent sample of the population and for 2005-2010 the ACS is a

\footnotetext{
${ }^{7}$ One subtle difference is that while the Census was conducted for a single point in time (April 1), the ACS is administered continuously throughout the year.
} 
one percent sample of the U.S. population. We use Census provided weights in our analysis, so that each year is given roughly equal weight. ${ }^{8}$

Our primary interest is in the effects of merit programs on college degree completion. However, we also consider the effect of merit programs on the likelihood of completing any college. Merit programs could have short run timing effects by encouraging some people to enroll at younger ages who would have eventually matriculated later, but our analysis measures longer run effects. Our second education outcome is whether an individual has completed any college degree including an associate's degree or higher. However, there is a considerable difference in both the private and social benefits between completing an associate's degree and completing a bachelor's degree or higher. Thus, our third outcome is whether an individual has completed a bachelor's degree or higher. One might also be interested in whether state merit aid programs affected completion of post-baccalaureate degrees. In results not shown, we do consider the effects of merit programs on graduate degrees and find small insignificant effects. However, since merit programs cannot be used for graduate education we do not focus on advanced degrees.

The PUMS also include information on an individual's age, sex, race, Hispanic origin, and state of birth; we use these in our analysis. For our baseline analysis we restrict the sample to persons between the ages of 24 and 30. We exclude persons below age 24 because we are primarily interested in longer run effects of merit programs on college attendance and completion and not on whether merit programs altered the timing of these outcomes. The upper age cutoff is more arbitrary but was chosen in part because only a few states adopted programs early enough that persons exposed to a merit program were older than age 30 during our sample

\footnotetext{
${ }^{8}$ The weights in each sample sum to the total population in that year. We also reweight the 2000 PUMS to avoid giving that year double weight since we are using two samples instead of one. The results below are qualitatively robust to not using weights.
} 
period. The results are robust to varying the upper and lower age cutoffs, suggesting that meritbased aid programs did not alter the timing of degree completion. We also exclude from the sample individuals with imputed information for age, education or state of birth, but results are robust to including these individuals.

Similarly to Dynarski (2008) we also collect information on a few state level variables intended to control for macroeconomic conditions in an individual's state of birth for the year the individual was 18 years of age. First, previous researchers have found that larger cohorts of college age persons in a state have lower college enrollment and degree completion rates, likely because states face some supply constraints in providing higher education (Card and Lemieux 2000; Bound and Turner 2007). We obtain data from the U.S. Census Bureau on the number of 18 year olds in the state in a given year (measured for July) and convert to logs and use this to control for cohort size in a state and year. The unemployment rate might also affect an individual's decision to attend college because a more difficult job market can reduce a young person's opportunity cost of attending college and make them more likely to enroll. We collect state by year unemployment rates from the Bureau of Labor Statistics (BLS) and include this as another control variable. We also control for median household income and the college wage premium in the individual's state of birth the year the individual was 18 years old, both computed using the March Current Population Survey (CPS). Greater household income suggests greater parental resources that make college more attainable for marginal students. The college wage premium is computed as the logarithmic difference in annual wage and salary income between persons with only a bachelor's degree and persons with only a high school diploma, using linear regression to control for age, sex, race, and Hispanic origin; the college wage premium CPS sample is also restricted to paid employees ages 25-54 who work at least 35 
hours per week and 35 weeks during the year. The college wage premium signals to young people the potential benefits of attending college with a higher wage premium making college more appealing.

\section{Research Design}

We follow a treatment and control research design. The treatment group consists of individuals who were exposed to a broad-based state merit aid program when they graduated high school and the control group consists of individuals who were not. Unfortunately, we do not know when and where individuals graduated high school. We follow previous literature (e.g. Dynarski 2008, Hickman 2009) and assign individuals to the merit program treatment group based on state of birth and year of birth, where year of birth is computed as the year of the survey minus age at the time of the survey. If an individual was born in a state that adopted a merit program and turned 18 after the program was implemented, they are assigned to the treatment group; if not they are part of the control group. The control group, therefore, includes both individuals born in states that never adopted merit programs and individuals born in meritadopting states but turning 18 before the program was implemented. Because some individuals attend high school outside their state of birth and some do not graduate high school at age 18, our treatment assignment will have some degree of measurement error. We take up the issue of measurement error in more detail later.

As noted above we identified 25 states that implemented a merit scholarship program between 1991 and 2004 (Table 1). ${ }^{9}$ Eligibility requirements are typically based on high school GPA, often requiring a 3.0 or higher, but there is often a standardized test score requirement and

\footnotetext{
${ }^{9}$ Delaware, Massachusetts, Montana, and Wyoming also implemented programs in 2005 and 2006 but these do not affect our main sample because persons 18 years old in 2005 and 2006 are only 23 and 22 years old in 2010, the last year of our sample.
} 
occasionally an income/asset requirement. Some states allow students at in-state private colleges and universities to be eligible for a scholarship while others restrict eligibility to students enrolled at public colleges and universities in the state. Renewal requirements are typically based on college GPA but can also include minimum course load requirements as in West Virginia. Award values range from $\$ 500$ per year to full tuition and fees at in-state public colleges and universities plus a book stipend. A few states also have multiple award levels based on different eligibility criteria. Dynarski (2004), Heller (2004), and the Brookings Institution ${ }^{10}$ provide useful details for most states.

One might be interested in examining the effects of specific merit program characteristics on educational outcomes, but there are problems with doing so. First, there is a dimensionality problem since many states have relatively unique characteristics. Similarly, there is a classification problem because converting program requirements to usable data requires considerable information and a fairly large number of arbitrary classification decisions to be made; this is greatly complicated by the fact that many states changed their program's characteristics several times since inception. The Georgia HOPE Scholarship provides a useful illustration; a detailed history is provided by Sjoquist and Walker (2010) so we only discuss a few important changes. The Georgia HOPE scholarship was initially only available to students with a family income below $\$ 66,000$ per year but the income limit was increased to $\$ 100,000$ in 1994 and eliminated in 1995. HOPE eligibility was initially based on a student's overall high school GPA but in Fall 2000 Georgia switched to a more stringent core course GPA that excluded electives and reduced the percentage of students eligible for HOPE. The program also initially required students to complete the FAFSA and the amount of the HOPE scholarship was

\footnotetext{
${ }^{10}$ Brookings Institution data file is available at http://www.brookings.edu/research/reports/2012/05/08-grantschingos-whitehurst
} 
reduced by any Pell Grant award. However, the Pell offset was eliminated in 2000 allowing eligible students to receive both a Pell Grant and a full HOPE Scholarship. Over time other changes were made as well, including allowing students to regain HOPE after previously losing it, allowing home schooled students to be eligible, increasing the value of the award at Georgia private schools, and setting a cap on the total credit hours for which HOPE would pay.

Instead of trying to isolate the effects of specific merit program characteristics we adopt a much simpler approach that uses a dummy variable equal to one if an individual was exposed to a merit program. However, we recognize that some of these state programs are relatively small and not likely to have a sizable impact on education outcomes. Based on program characteristics we identify nine states that adopted "strong" merit programs: Florida, Georgia, Kentucky, Louisiana, Nevada, New Mexico, South Carolina, Tennessee, and West Virginia. The other 16 states are considered to have "weak" programs. The nine strong states are defined as such because they have large broad-based programs that provide relatively large awards. Most of the other merit states have relatively strict criteria that limit eligibility to either the very best students or students with relatively low income. Two of the 16 states, Michigan and Mississippi, also have broad-based programs but are excluded from the group of "strong" states because they offer relatively small awards to most students. ${ }^{11}$ Michigan's program which was discontinued after 2008 provided a one-time award of $\$ 2500$ and the Mississippi TAG program offered only $\$ 500$ for the first two years of college and $\$ 1000$ for the third and fourth years. The "strong" programs provide scholarships large enough to cover full tuition or nearly full tuition at public

\footnotetext{
${ }^{11}$ Dynarksi (2004) lists 13 states with eligibility criteria such that "at least 30 percent of high school students hav[e] grades and test scores high enough to qualify for a scholarship" (p. 65). These include the nine strong states, Michigan, Mississippi, Arkansas, and Maryland. However, Arkansas and Maryland enforced income limits that rendered them considerably less broad-based than the other 11.
} 
colleges and universities in the state. The results below are qualitatively robust to several alternative definitions of "strong" states such as including Michigan and Mississippi.

In results not shown, we did estimate a regression equation that included a dummy variable equal to one if the state required the student to take a full load to receive a merit scholarship and results were similar to those using the simple merit dummy. Later, we also estimate separate merit effects for each merit state; doing so could help shed light on which program characteristics matter if any.

Our preferred specification for assessing the effects of broad-based merit scholarship programs on higher education outcomes is to compare states with strong merit programs to states with no merit program. Weak program states receive only a "partial treatment" compared to the "full treatment" of strong program states and are less likely to have large impacts on educational outcomes. Thus, including weak merit states in the treatment group is likely to attenuate coefficient estimates toward zero. However, they do receive some treatment so including weak merit states in the control group is also likely to attenuate coefficient estimates toward zero. The purest test is to exclude weak merit states from the analysis and estimate the effect of state merit programs based on states with strong programs and states with no program. We do, however, examine the robustness of our results to including weak merit states in the analysis.

For each of the three binary educational outcomes that we consider as dependent variables, we estimate linear probability models (LPM) as follows:

$$
P\left(Y_{i s t}=1\right)=\Gamma_{s}+\Pi_{t}+\beta X_{i s t}+\delta Z_{s t}+\theta \text { Merit }_{s t}+\varepsilon_{i s t},
$$

where $\Gamma_{s}$ includes state of birth fixed effects, $\Pi_{t}$ includes year of birth fixed effects, $X$ includes dummy variables for individual characteristics including sex, race, Hispanic origin, and age, $Z$ includes the state of birth characteristics at age 18 discussed previously, and Merit is an 
indicator variable equal to one if the individual was exposed to a state merit program and zero otherwise. The state of birth and year of birth fixed effects allow the model to be interpreted as a difference in differences model identified by differences across birth states and across birth cohorts within birth states. The models are estimated via Ordinary Least Squares (OLS) but results are robust to using probit or logit. Summary statistics for the variables in this study are reported in Table 2 separately for strong merit, weak merit, and non-merit birth states. The strong merit birth states have much lower educational outcomes than both the weak merit and non-merit states. There are also meaningful differences in some of the explanatory variables, so these maybe important factors. We consider the effects of excluding and progressively including the individual and state characteristics.

Because we use individual level data and the Merit variable is defined based on state and year of birth, OLS standard errors should not be used because they do not account for intracluster correlation (Bertrand, Duflo, and Mullainathan 2004; Donald and Lang 2007; Cameron, Gelbach and Miller 2008). Instead, we report both standard errors clustered by state of birth and 95\% confidence intervals based on procedures suggested by Conley and Taber (2011). Clustered standard errors are typically preferred to OLS standard errors but Conley and Taber (2011) show that clustered standard errors can be downwardly biased when the number of policy changes is small. They suggest a confidence interval procedure based on the distribution of residuals across the control states and show that their procedure outperforms conventional clustered standard errors when there are a small number of treatment groups and does no worse more generally. Our preferred specification includes 9 states with policy changes, so we report both clustered standard errors and Conley-Taber confidence intervals. 


\section{Empirical Results for Census/ACS Analysis}

\section{Basic Results}

Table 3 reports results that start off with a limited set of control variables and then progressively add more detailed controls. Persons born in weak merit states are excluded. The treatment group includes only persons born in strong merit states who were exposed to a strong merit program. The control group includes persons born in non-merit states and persons born in strong merit states but reaching age 18 before the merit program was implemented. The first column of Table 3 includes only state of birth, year of birth and age dummies. The second column adds dummies for sex, race, and Hispanic origin and the third adds the state level controls. We also include state of birth by year of birth time trends in the fourth column but this is not our preferred specification because merit program effects may increase over time causing them to be captured by the state of birth time trend instead of the merit dummy. Our preferred specification is in the third column. The effects of state merit aid programs on each of the three educational outcomes are reported in Panels A, B, and C.

The results in Table 3 tell a consistent story. The coefficient estimates are small and close to zero for every regression; 11 of the 12 coefficients are negative and only one is positive, but the magnitudes are all less than one percentage point. Adding the additional controls increases the coefficient estimates relative to column 1 but only slightly. Furthermore, all of the coefficient estimates are statistically insignificant using both clustered standard errors and Conley-Taber 95\% Confidence Intervals. The confidence intervals are also fairly narrow and allow us to reject hypotheses of large effects. These results, therefore, suggest that state meritbased financial aid programs had no meaningful effect on college attendance or degree completion. 


\section{Different Definitions of Treatment and Control Groups}

Table 4 considers how the results are affected by altering the assignment of states to the treatment and control groups. The first column of Table 4 replicates the third column of Table 3 , our preferred specification. The second column of Table 4 includes weak merit states in the analysis and includes individuals exposed to weak merit programs as part of the treatment group. The third column of Table 4 includes all persons born in weak merit states as part of the control group. One might be concerned that the non-merit states are somehow different from merit states and make a poor control group. To address such concerns, the control group for the fourth and fifth columns of Table 4 only includes persons born in merit states but who are too old to have been exposed to a merit program in their state of birth. The fourth column limits the sample to persons born in strong merit states. The fifth column limits the sample to persons born in strong or weak merit states and includes persons exposed to weak merit programs in the treatment group. However, having no states without policy changes in the control group prevents us from estimating Conley-Taber confidence intervals for the last two columns.

The results in Table 4 are quite consistent as well. The coefficient estimates in columns 2 and 3 are slightly larger than in column 1 but still negative for five of the six regressions and in no case statistically significant. The coefficient estimates in the fourth and fifth columns are also small and statistically insignificant for five of the six regressions. The exception is for bachelor's degrees or higher in the fourth column, which has a coefficient of -0.0058 and is significant at the ten percent level based on standard errors clustered by state of birth. However, this magnitude is relatively small and having only nine states suggests clustered standard errors are likely to be downwardly biased, so we do not interpret this as convincing evidence of a 
significant negative effect. Table 4 as a whole provides consistent and convincing evidence that merit programs had no meaningfully positive effects on college attainment.

\section{Accounting for Measurement Error in Treatment Status}

Table 5 presents results that account for measurement error in treatment status. The results in the rest of this paper assign an individual to the treatment group if they were born in a state that adopted a merit program and turned 18 after the program was implemented. However, some individuals attend high school outside their state of birth and some finish high school before or after age 18. To account for measurement error due to age when finishing high school, the first column of Table 1 excludes from the sample persons who were ages 18 or 19 when a merit program was implemented in their birth state. ${ }^{12}$ The earlier analysis assigns those who were 18 years old when the program was first implemented to the treatment group and those who were 19 years old to the control group. But some who were 18 when the program started could have finished high school a year earlier at age 17 and not been eligible. Similarly, some individuals who were 19 when the program started could have graduated high school at 19 and been eligible for the merit program. Column 1 of Table 5 excludes these "marginal" birth cohorts from the analysis to reduce measurement error. The coefficient estimates are now slightly more negative than the preferred specification in Table 3 column 3 , but the difference is slight. The coefficient for bachelor's degrees or above is significant based on clustered standard errors but not significant using Conley-Taber 95\% confidence intervals.

We next account for measurement error in treatment assignment due to persons attending high school outside their state of birth. ${ }^{13}$ Following Dynarski (2008) we explore measuring merit

\footnotetext{
${ }^{12}$ Results are also robust to excluding those who were ages 17 and 20 when the merit program in their state began.

${ }^{13} 76$ percent of 18 year olds in the Census/ACS live in their birth state.
} 
exposure based on the predicted probability of going to high school in a merit state based on state of birth. Using the sample of 15-17 year olds in the 2000 Census and 2001-2010 ACS, for each merit state we regress the probability of living in that state during high school on a complete set of state of birth dummies. We then use the predicted values and year of birth to compute the probability that an individual was exposed to a merit program. ${ }^{14}$ We then replace the merit dummy in our education outcomes LPM models with the probabilistic merit variable. Results are reported in column 2 of Table 5 and are very similar to those for the preferred specification. The coefficient estimates are small, negative, and statistically insignificant.

The third column of Table 5 combines the procedures in the first two columns to account for measurement error in treatment due to both state and year of birth. The results tell a familiar story. The coefficients are small, negative, and insignificant. Thus accounting for measurement error in treatment status does not change the basic results. There is no evidence of a meaningful positive effect of state merit aid programs on college attendance or degree completion.

\section{Effects by Sex and Race/Ethnicity}

Table 6 presents results for merit program effects by sex and race/ethnicity. The first two columns reports results for white non-Hispanic males and white non-Hispanic females. The third and fourth columns report results for non-white or Hispanic males and non-white or Hispanic females. The coefficient estimates are typically small and negative and are in no case statistically significant based on Conley-Taber confidence intervals. It is worth noting that the coefficient for college attendance for non-white or Hispanic males is -0.0199 which is the largest coefficient in absolute value seen thus far. However, as seen by the Conley-Taber confidence intervals, restricting the analysis to this group produces fairly noisy estimates. The results in

\footnotetext{
${ }^{14}$ Predicted probabilities by year and state of birth are available from the authors by request.
} 
Table 6 suggest that there is no meaningful positive effect of state merit aid programs on college attainment for demographic subgroups.

\section{Effects by Age}

We next examine merit effects on college attainment by age for persons between ages 22 and 31. Results are reported in Table 7. Looking at ages 22 and 23 allows us to examine if there are any short run timing effects due to merit programs causing students to finish degrees more quickly. Age 31 is examined for the sake of robustness but only three strong merit states (Georgia, Florida, and New Mexico) have persons eligible for a merit program reach age 31 by 2010. Only Georgia has merit eligible individuals reach ages $32-35$, so we do not report results for these ages. Additionally, since the older ages are achieved by fewer merit states and hence are identified based on fewer policy changes they will have wider Conley-Taber confidence intervals.

Most of the coefficients in Table 7 are small and statistically insignificant but there are a few exceptions. First, the associate's degree or higher coefficient for 22 year olds is -0.0182 and is statistically significant according to Conley-Taber $95 \%$ confidence intervals. However, for 24 year olds we observe the exact opposite result; the coefficient for associate's or higher is significantly positive and of the same magnitude. The only other individually significant result based on Conley-Taber confidence intervals is the coefficient of -0.0291 for any college for age 26. Considering that Table 7 estimates 30 regressions it is not surprising to observe individually significant effects for a few of them. However, the results in Table 7 do not suggest consistent effects by age. They also do not suggest that there were any merit-induced timing effects in college attainment. 


\section{Effects by Birth State}

Table 8 estimates separate effects for all 25 merit states to examine if there are any meaningful merit effects for individual states that are not detectable from the average effect over several states. The analysis is the same as in the preferred specification except that each regression includes only one treatment state; the other 24 merit states are excluded. We report Conley-Taber 90\% confidence intervals because having only 27 total states (one merit state and 26 non-merit states) for each regression prevents us from computing the $95 \%$ confidence intervals. Including only one treatment state also decreases the precision of the estimates and widens the confidence intervals, especially for states that have only a few birth cohorts exposed (or not exposed) to their merit program. Having only one merit state per regression also means that clustered standard errors are severely biased so we do not report them in order to conserve space.

The coefficient estimates for individual states are more dispersed as expected, but they are generally small and not statistically significant, with a few exceptions. Only five of the 75 regression coefficients are significant at the $10 \%$ level; all five are negative and for weak merit states. These include the any college coefficients for Alaska and Washington and the associate's or higher coefficients for Idaho, Utah, and Washington. The largest positive coefficients for degree completion were for Maryland, South Dakota, and West Virginia, all of which have bachelor's degree coefficients just above two percentage points. However, only West Virginia has a strong merit program and all of these were adopted fairly recently and have only a few treated cohorts. Maryland and West Virginia have only three years of birth cohorts included in the treatment and South Dakota has only one cohort in the treatment. Consequently, the coefficients are not precisely estimated and the confidence intervals are wide enough that none of 
these are statistically significant. Furthermore, estimating regressions for many individual states we would expect the coefficient estimates to be distributed around the true coefficient. Finding a few coefficients that are slightly positive is not surprising. Looking at individual states provides further evidence that state merit aid programs have no meaningfully positive effect on college attendance and completion.

\section{Empirical Framework for University System of Georgia Analysis}

We next explore the effects of the Georgia HOPE Scholarship on educational outcomes using administrative data for the University System of Georgia (USG). The USG is a statewide higher education system that includes a total of 35 two- and four-year colleges and universities in Georgia. In 1990 the USG made up 72 percent of total undergraduate enrollment in the state (NCES 1995). We obtained individual student data for four cohorts of first-time freshmen from the USG Board of Regents. ${ }^{15}$ The data include all Georgia residents who graduated high school in Georgia in 1990, 1991, 1995 and 1996 and matriculated in the USG in the summer or fall immediately after high school. Data were obtained for the 1995 and 1996 cohorts instead of the 1993 and 1994 cohorts because these first two post-HOPE cohorts were initially subject to an income cap for eligibility. The 1992 cohort was not included because of concerns that some students could have anticipated HOPE and changed their behavior in anticipation.

We examine the effects of the HOPE Scholarship on degree completion in the USG using a cohort analysis. We consider two main outcomes: 1) completion of an associate's or bachelor's degree and 2) completion of a bachelor's degree. We look at differences in these outcomes between the pre- and post-HOPE cohorts after four, five, six, and twelve years after graduating high school and enrolling in the USG. In addition to information on associate's and

\footnotetext{
${ }^{15}$ Our agreement with the Board of Regents limited our data request to four cohorts of students.
} 
bachelor's degrees awarded, the USG data also include sex, race, Hispanic origin, high school attended, SAT score, and core course high school GPA. Since previous literature suggests that HOPE caused average student quality in the USG to increase, we will control for this when making before and after HOPE comparisons. The linear probability model is as follows:

$$
P\left(Y_{i t}=1\right)=\beta X_{i t}+\theta P o s t H O P E_{t}+\varepsilon_{i t},
$$

Where $X$ includes dummy variables for sex, race, Hispanic origin, high school attended, SAT score, and high school GPA, PostHOPE is a dummy equal to one for the 1995-96 cohorts and zero for the 1990-91 cohorts. ${ }^{16}$ Therefore, $\theta$ measures the effect of the HOPE program on degree completion in the USG holding student quality and demographics constant.

Note that the PostHOPE dummy equals one for all students in the post-HOPE cohort and not just students who received the HOPE Scholarship. We do not have the HOPE GPA needed to determine if pre-HOPE students would have qualified for HOPE had it existed. Henry, Rubenstein, and Bugler (2004) limit their analysis to post-HOPE students and estimate the effects of actual HOPE receipt on four-year degree completion based on differences between students with similar core GPAs but different HOPE GPAs. However, even controlling for core GPA, post-HOPE students who qualify for HOPE are likely higher quality and more motivated than those who do not. For example, marginal students with more to gain from receiving a HOPE Scholarship are more likely to take actions to gain eligibility such as taking more electives courses to boost their GPA above a 3.0. Less motivated students are less likely to take such actions to earn a HOPE Scholarship but are also less likely to take the necessary actions to succeed in college.

\footnotetext{
${ }^{16} \mathrm{We}$ also experimented with controlling for USG institution attended. Doing so does not meaningfully change the results.
} 


\section{Empirical Results for University System of Georgia Analysis}

Table 9 presents the results for the USG analysis. Panel A presents results for completing an associate's or bachelor's degree and Panel B presents results for completing a bachelor's degree. The first column contains no control variables. The second column includes dummies for sex, race, Hispanic origin, and high school attended, but not SAT or high school GPA. The third column adds SAT dummies and the fourth adds high school GPA dummies. There is an important caveat for the fourth column. Sjoquist and Winters (2012b) argue that HOPE caused high school grade inflation for post-HOPE cohorts in Georgia. Inflated high school GPAs for post-HOPE students mean that one should be very cautious in interpreting results that control for high school GPA because looking at students with the same GPA compares lower quality postHOPE students to higher quality pre-HOPE students. Since student quality is strongly positively correlated with degree completion, grade inflation will create a negative bias in $\theta$ when controlling for high school GPA. Our preferred estimates, therefore, do not control for high school GPA, but we also report results that do. SAT score increases represent actual increases in student quality and should be controlled for, so our preferred specification is the third column that includes all of the controls except for high school GPA.

The results with no controls in the first column suggest a relatively small increase in degree completion in Panel A but a larger increase in Panel B for bachelor's degrees. The effects for bachelor's degrees are statistically significant for four, five, six, and twelve years after starting college based on standard errors clustered by year and the magnitudes increase slightly over time. However, there are only four cohorts so clustered standard errors should be interpreted with caution. The Conley-Taber procedure is not feasible since we have administrative data for only one state. Adding dummies for sex, race, Hispanic origin and high 
school attended in the second column increases the coefficients slightly. However, controlling

for student quality by adding the SAT score dummies in the third column reduces the coefficient estimates to roughly zero and makes them statistically insignificant. Adding high school GPA dummies in the fourth column causes the coefficient estimates to be negative and significant, which likely results from the negative bias created by post-HOPE grade inflation. The results for the preferred specification in column 3 suggest that controlling for changes in student quality using SAT scores HOPE had no meaningful effect on degree completion rates in the USG. These results reinforce our findings using the Census/ACS data.

\section{Conclusion}

Increasing the percentage of young people with a college education is an important goal for society but there is little consensus on how that can be best achieved. Providing financial aid, both need-based and merit-based, is often advocated as a useful policy tool. We examine the effects of recently adopted state merit-based financial aid programs on college attendance and degree completion. The small literature that exists has only looked at one or two states at a time and has provided mixed results. Our main analysis utilizes public use microdata samples from the 2000 Census and 2001-2010 American Community Survey (ACS) which allows us to estimate the effects of merit programs on educational outcomes for nine states with strong merit programs and 16 other states with weaker merit programs. We also utilize administrative student records for the University System of Georgia (USG) to take a more in depth look at the effects of the HOPE Scholarship on degree completion in Georgia.

We find strong consistent evidence that state merit aid programs had no meaningfully positive effect on college attendance or degree completion. The coefficient estimates for our 
preferred Census/ACS specification are small, negative, and statistically insignificant. We also consider a number of different robustness checks including varying the states included in the analysis and estimating separate merit effects for each of the 25 merit states. Coefficient estimates for the robustness checks are typically small and statistically insignificant, and more frequently negative than positive. Our preferred specification for the USG analysis also yields small and insignificant effects of the HOPE Scholarship on degree completion. While state merit aid programs may produce other benefits for their states, they do not appear to be effective at increasing the percentage of young people with a college education.

Scott-Clayton (2011) argues that her results for West Virginia are driven by the requirement that to retain eligibility students must be enrolled full time. We use the Census/ACS data to explore this using a dummy variable equal to one if the state had such a requirement and found no effect. For the individual state regressions (Table 8) we do find that the merit dummy coefficients for West Virginia are positive for the degree completion regressions, but they are not statistically significant. For the other two states with strong merit aid programs that have a similar enrollment requirement (New Mexico and South Carolina), the coefficients on merit aid are negative and insignificant. Thus, we find no evidence that a full load requirement has an effect on college completion. 


\section{References}

Bertrand, Marianne, Esther Duflo, and Sendhil Mullainathan (2004). "How Much Should We Trust Differences-in-Differences Estimates?" Quarterly Journal of Economics 119(1):249-75.

Bound, John and Sarah Turner (2007). "Cohort Crowding: How Resources Affect Collegiate Attainment." Journal of Public Economics, 91 (5-6), 877-899.

Bruce, Donald J. and Celeste K. Carruthers (2011). "Jackpot? The Impact of Lottery Scholarships on Enrollment and Earnings in Tennessee." Working paper, University of Tennessee.

Cameron, A. Colin, Jonah B. Gelbach, and Douglas L. Miller (2008). "Bootstrap-Based Improvements for Inference with Clustered Errors." Review of Economics and Statistics 90(3):414-27.

Card, David, and Thomas Lemieux (2000). "Dropout and Enrollment Trends in the Post-War Period: What Went Wrong in the 1970s?" In J. Gruber, An Economic Analysis of Risky Behavior Among Youth (pp. 439-482). Chicago: University of Chicago Press.

Conley, Timothy G., and Christopher R. Taber (2011). "Inference with 'Difference in Differences' with a Small Number of Policy Changes.” Review of Economics and Statistics 93(1):113-25.

Cornwell, Christopher M., Kyung Hee Lee, and David B. Mustard (2005). Student Responses to Merit Scholarship Retention Rules.” Journal of Human Resources 40(4):895-917.

Cornwell, Christopher, David B. Mustard, and Deepa Sridhar (2006). "The Enrollment Effects of Merit-Based Financial Aid: Evidence from Georgia's HOPE Program.” Journal of Labor Economics 24(4): 761-86.

Donald, Stephen G., and Kevin Lang (2007). "Inference with Difference-in-Differences and Other Panel Data." Review of Economics and Statistics 89(2):221-33.

Dynarski, Susan (2000). "Hope for Whom? Financial Aid for the Middle Class and Its Impact on College Attendance." National Tax Journal Part 2 53(3):629-61.

Dynarski, Susan (2004). “The New Merit Aid”. In College Choices: The Economics of Which College, When College, and How to Pay for It. Caroline M. Hoxby (ed) Chicago: University of Chicago Press. Pp. 63-97.

Dynarski, Susan (2008). "Building the Stock of College-Educated Labor." Journal of Human Resources 43(3):576-610. 
Farrell, Patricia L., and Gregory S. Kienzl (2009). “Are State Non-Need, Merit-Based Scholarship Programs Impacting College Enrollment?" Education Finance and Policy, 4(2), 150-174.

Goldrick-Rab, Sara, Douglas N. Harris and Philip A. Trostel (2009). "Why Financial Aid Matters (or Does Not) for College Success: Toward a New Interdisciplinary Perspective." In In John C. Smart (Ed), Higher Education: Handbook of Theory and Research, volume 24. The Netherlands: Springer, 1-45.

Goodman, Joshua (2008). "Who Merits Financial Aid?: Massachusetts' Adams Scholarship" Journal of Public Economics 92: 2121-2131.

Hawley, Zackary B. and Jonathan C. Rork (2012). "The Case of State Funded Higher Education Scholarship Plans and Interstate Brain Drain.” Regional Science and Urban Economics, Forthcoming.

Heller, Donald E. (2004). "State merit scholarship programs: An overview." In Donald E. Heller \& Patricia Marin, State merit scholarship programs and racial inequality (pp. 1-22). Cambridge, MA: The Civil Rights Project, Harvard University.

Henry, Gary T., Ross Rubenstein, and Daniel T. Bugler (2004). "Is HOPE Enough? Impacts of Receiving and Losing Merit-Based Financial Aid.” Educational Policy 18(5):686-709.

Hickman, Daniel C. (2009). "The Effects of Higher Education Policy on the Location Decision of Individuals: Evidence from Florida's Bright Futures Scholarship Program." Regional Science and Urban Economics, 39 (5), 553-562.

Imbens, Guido W. and Thomas Lemieux (2008). "Regression Discontinuity Designs: A Guide to Practice." Journal of Econometrics 142 (2): 615-635.

Melguizo, Tatiana (2011). "A Review of the Theories Developed to Describe the Process of College Persistence and Attainment.” In John C. Smart and Michael B. Paulsen (Eds), Higher Education: Handbook of Theory and Research, volume 26. The Netherlands: Springer, 395-424.

National Center for Education Statistics (1995). Digest of Education Statistics. Washington, DC: U.S. Department of Education.

National Center for Education Statistics (2012). Integrated Postsecondary Education System (IPEDS), Graduation Rates component. U.S. Department of Education. Available at http://nces.ed.gov/ipeds/datacenter/Default.aspx , accessed July 17, 2012.

Orsuwan, Meechai, and Ronald H. Heck (2009). "Merit-Based Student Aid and Freshman Interstate College Migration: Testing A Dynamic Model of Policy Change." Research in Higher Education, 50 (1), 24-51. 
Passty, Benjamin W. (2012). “The Good Ones Go Fast: Education, Merit Aid, and Marriage Outcomes" Working Paper, University of Cincinnati.

Resmovits, Joy (2012). “Arne Duncan To Report College Completion Rates Rise By Half A Percentage Point." Huffington Post. July 12, 2012. Available at http://www.huffingtonpost.com/2012/07/12/arne-duncan-college-completion-nationalgovernors-association-conference_n_1666529.html, accessed July 17, 2012.

Ruggles, Steven J., Trent Alexander, Katie Genadek, Ronald Goeken, Matthew B. Schroeder, and Matthew Sobek (2010). Integrated Public Use Microdata Series: Version 5.0 [Machine-readable database]. Minneapolis: University of Minnesota.

Scott-Clayton, Judith (2011). "On Money and Motivation: A Quasi-experimental Analysis of Financial Incentives for College Achievement.” Journal of Human Resources 46(3): 614646.

Singell, Larry D., Glen R. Waddell, and Bradley R. Curs (2006). "HOPE for the Pell? Institutional Effects in the Intersection of Merit-Based and Need-Based Aid." Southern Economic Journal, 73 (1), 79-99.

Sjoquist, David L., and Mary Beth Walker (2010). Informing Lottery Budget Decisions: HOPE and Pre-K. FRC Report 215, Atlanta, GA: Fiscal Research Center, Andrew Young School of Policy Studies, Georgia State University.

Sjoquist, David L., and John V. Winters (2012a). "Building the Stock of College-Educated Labor Revisited." Journal of Human Resources 47(1): 270-285.

Sjoquist, David L., and John V. Winters (2012b). “The Effects of HOPE on Post-College Retention in the Georgia Workforce" Working Paper, Georgia State University.

Titus, Marvin A. (2006). "No College Student Left Behind: The Influence of Financial Aspects of a State's Higher Education Policy on College Completion" The Review of Higher Education 29 (3): 293-317.

Winters, John V. (2012). "Cohort Crowding and Nonresident College Enrollment." Economics of Education Review, 31(3): 30-40.

Zhang, Liang, and Erik C. Ness. (2010). "Does State Merit-Based Aid Stem Brain Drain?" Educational Evaluation and Policy Analysis, 32 (2), 143-165. 
Table 1: States with Strong and Weak Merit Programs Implemented 1991-2006

\begin{tabular}{|c|c|c|}
\hline State & First Cohort & Program Name \\
\hline \multicolumn{3}{|c|}{ A. Strong Merit Programs } \\
\hline Florida & 1997 & Florida Bright Futures Scholarship \\
\hline Georgia & 1993 & Georgia HOPE Scholarship \\
\hline Kentucky & 1999 & Kentucky Educational Excellence Scholarship \\
\hline Louisiana & 1998 & Louisiana TOPS Scholarship \\
\hline Nevada & 2000 & Nevada Millennium Scholarship \\
\hline New Mexico & 1997 & $\begin{array}{l}\text { New Mexico Lottery Success Scholarship } \\
\text { South Carolina LIFE Scholarship (HOPE }\end{array}$ \\
\hline South Carolina & $1998(2001)$ & Scholarship) \\
\hline Tennessee & 2003 & Tennessee HOPE Scholarship \\
\hline West Virginia & 2002 & West Virginia PROMISE Scholarship \\
\hline \multicolumn{3}{|c|}{ B. Weak Merit Programs Implemented 1991-2004 } \\
\hline Alaska & 1999 & Alaska Scholars \\
\hline Arkansas & 1991 & Arkansas Academic Challenge Scholarship \\
\hline California & 2001 & Competitive Cal Grant Program \\
\hline Idaho & 2001 & Robert R. Lee Promise Category B Scholarship \\
\hline Illinois & 1999-2004 & Illinois Merit Recognition Scholarship \\
\hline Maryland & 2002-2005 & Maryland HOPE Scholarship \\
\hline Michigan & $2000-2008$ & Michigan Merit Award \& Promise Scholarship \\
\hline Mississippi & 1996 & Mississippi TAG and ESG \\
\hline Missouri & 1997 & Missouri Bright Flight Scholarship \\
\hline New Jersey & $1997(2004)$ & New Jersey OSRP (STARS) \\
\hline New York & 1997 & New York Scholarships for Academic Excellence \\
\hline North Dakota & 1994 & North Dakota Scholars Program \\
\hline Oklahoma & 1996 & Oklahoma PROMISE Scholarship \\
\hline South Dakota & 2004 & South Dakota Opportunity Scholarship \\
\hline Utah & 1999 & New Century Scholarship \\
\hline Washington & 1999-2006 & Washington PROMISE Scholarship \\
\hline \multicolumn{3}{|c|}{ C. Weak Merit Programs Implemented 2005-2006 } \\
\hline Delaware & 2006 & Delaware SEED Scholarship \\
\hline Massachusetts & 2005 & John \& Abigail Adams Scholarship \\
\hline Montana & 2005 & Governor's Best and Brightest Scholarship \\
\hline Wyoming & 2006 & Hathaway Scholarship \\
\hline
\end{tabular}


Table 2: Summary Statistics for Strong, Weak and Non-Merit Birth States, 2000-2010 Census/ACS

\begin{tabular}{lcccccc}
\hline & \multicolumn{2}{c}{ Strong Merit } & \multicolumn{2}{c}{ Weak Merit } & \multicolumn{2}{c}{ Non-Merit } \\
& Mean & S.D. & Mean & S.D. & Mean & S.D. \\
\hline Any College & 0.562 & 0.496 & 0.656 & 0.475 & 0.635 & 0.481 \\
Associate's Degree + & 0.315 & 0.464 & 0.392 & 0.488 & 0.388 & 0.487 \\
Bachelor's Degree + & 0.234 & 0.424 & 0.302 & 0.459 & 0.300 & 0.458 \\
Merit & 0.415 & 0.493 & 0.323 & 0.468 & 0.000 & 0.000 \\
Age & 26.967 & 1.998 & 26.965 & 2.004 & 26.978 & 2.001 \\
Female & 0.511 & 0.500 & 0.504 & 0.500 & 0.505 & 0.500 \\
White & 0.696 & 0.460 & 0.677 & 0.467 & 0.767 & 0.422 \\
Black & 0.229 & 0.420 & 0.131 & 0.338 & 0.108 & 0.310 \\
Hispanic & 0.050 & 0.218 & 0.136 & 0.343 & 0.090 & 0.286 \\
Asian & 0.005 & 0.072 & 0.024 & 0.154 & 0.012 & 0.108 \\
Other & 0.020 & 0.140 & 0.031 & 0.172 & 0.024 & 0.152 \\
Log Cohort Size & 11.267 & 0.588 & 11.917 & 0.920 & 11.392 & 0.875 \\
Unemployment Rate & 5.576 & 1.271 & 5.918 & 1.488 & 4.969 & 1.306 \\
Log Median Household Income & 10.310 & 0.179 & 10.488 & 0.205 & 10.449 & 0.205 \\
Returns to BA Degree & 0.260 & 0.138 & 0.245 & 0.097 & 0.240 & 0.130 \\
Total Observations & 373,890 & $1,027,030$ & $1,100,230$ \\
\hline
\end{tabular}


Table 3: Merit Program Effects with and without Additional Demographic and State Variables

\begin{tabular}{|c|c|c|c|c|}
\hline & (1) & (2) & (3) & (4) \\
\hline \multirow[t]{3}{*}{ A. Any College } & -0.0046 & -0.0018 & -0.0026 & -0.0053 \\
\hline & $(0.0066)$ & $(0.0055)$ & $(0.0044)$ & $(0.0064)$ \\
\hline & {$\left[\begin{array}{ll}-0.0122 & 0.0129\end{array}\right]$} & {$\left[\begin{array}{ll}-0.0085 & 0.0154\end{array}\right]$} & {$\left[\begin{array}{ll}-0.0096 & 0.0126\end{array}\right]$} & {$\left[\begin{array}{lll}-0.0119 & 0.0021\end{array}\right]$} \\
\hline \multirow[t]{3}{*}{ B. Associate's Degree or Higher } & -0.0046 & -0.0016 & -0.0025 & 0.0011 \\
\hline & $(0.0040)$ & $(0.0029)$ & $(0.0027)$ & $(0.0037)$ \\
\hline & {$\left[\begin{array}{ll}-0.0100 & 0.0104\end{array}\right]$} & {$\left[\begin{array}{ll}-0.0070 & 0.0117\end{array}\right]$} & {$\left[\begin{array}{lll}-0.0074 & 0.0115\end{array}\right]$} & {$\left[\begin{array}{ll}-0.0036 & 0.0070\end{array}\right]$} \\
\hline \multirow[t]{3}{*}{ C. Bachelor's Degree or Higher } & -0.0063 & -0.0036 & -0.0045 & -0.0025 \\
\hline & $(0.0048)$ & $(0.0039)$ & $(0.0034)$ & $(0.0033)$ \\
\hline & {$\left[\begin{array}{ll}-0.0149 & 0.0096\end{array}\right]$} & {$\left[\begin{array}{ll}-0.0124 & 0.0101\end{array}\right]$} & {$\left[\begin{array}{ll}-0.0127 & 0.0067\end{array}\right]$} & {$\left[\begin{array}{ll}-0.0082 & 0.0046\end{array}\right]$} \\
\hline State of Birth Dummies & Yes & Yes & Yes & Yes \\
\hline Year of Birth Dummies & Yes & Yes & Yes & Yes \\
\hline Age Dummies & Yes & Yes & Yes & Yes \\
\hline Sex, Race, and Ethnicity Dummies & No & Yes & Yes & Yes \\
\hline \multicolumn{5}{|l|}{ Cohort Size, Unemployment, Median } \\
\hline Household Income, Returns to BA & No & No & Yes & Yes \\
\hline State of Birth*Year of Birth Trends & No & No & No & Yes \\
\hline Strong Merit States & Treatment & Treatment & Treatment & Treatment \\
\hline Weak Merit States & Excluded & Excluded & Excluded & Excluded \\
\hline Non-Merit States & Control & Control & Control & Control \\
\hline Ages Included & $24-30$ & $24-30$ & $24-30$ & $24-30$ \\
\hline Years Included & $2000-2010$ & $2000-2010$ & $2000-2010$ & $2000-2010$ \\
\hline
\end{tabular}

Notes: Standard errors in parentheses are clustered by state of birth. Conley-Taber $95 \%$ confidence intervals are in brackets. 
Table 4: Merit Program Effects for Different Treatment and Control States

\begin{tabular}{|c|c|c|c|c|c|}
\hline & $(1)$ & $(2)$ & $(3)$ & $(4)$ & $(5)$ \\
\hline A. Any College & $\begin{array}{c}-0.0026 \\
(0.0044) \\
{[-0.0096 \quad 0.0126]}\end{array}$ & $\begin{array}{c}-0.0025 \\
\left(\begin{array}{ll}0.0028) \\
{[-0.0040} & 0.0095\end{array}\right]\end{array}$ & 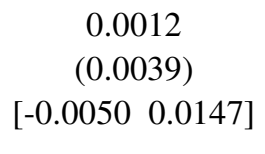 & $\begin{array}{c}-0.0081 \\
(0.0052) \\
{[\mathrm{N} / \mathrm{A}]}\end{array}$ & $\begin{array}{c}0.0005 \\
(0.0029) \\
{[\mathrm{N} / \mathrm{A}]}\end{array}$ \\
\hline B. Associate's Degree or Higher & $\begin{array}{c}-0.0025 \\
(0.0027) \\
{[-0.00740 .0115]}\end{array}$ & $\begin{array}{c}-0.0008 \\
(0.0028) \\
{[-0.00280 .0120]}\end{array}$ & $\begin{array}{c}-0.0005 \\
(0.0025) \\
{[-0.00600 .0142]}\end{array}$ & $\begin{array}{c}-0.0013 \\
(0.0034) \\
{[\mathrm{N} / \mathrm{A}]}\end{array}$ & $\begin{array}{c}0.0009 \\
(0.0031) \\
{[\mathrm{N} / \mathrm{A}]}\end{array}$ \\
\hline C. Bachelor's Degree or Higher & $\begin{array}{c}-0.0045 \\
(0.0034) \\
{[-0.01270 .0067]}\end{array}$ & $\begin{array}{c}-0.0033 \\
\left(\begin{array}{cc}0.0024) \\
{[-0.0063} & 0.0068\end{array}\right]\end{array}$ & $\begin{array}{c}-0.0011 \\
(0.0034) \\
{[-0.00860 .0122]}\end{array}$ & $\begin{array}{c}-0.0058 \\
(0.0030)^{*} \\
{[\mathrm{~N} / \mathrm{A}]}\end{array}$ & $\begin{array}{c}0.0004 \\
(0.0025) \\
{[\mathrm{N} / \mathrm{A}]}\end{array}$ \\
\hline State of Birth Dummies & Yes & Yes & Yes & Yes & Yes \\
\hline Year of Birth Dummies & Yes & Yes & Yes & Yes & Yes \\
\hline Age Dummies & Yes & Yes & Yes & Yes & Yes \\
\hline Sex, Race/Ethnicity Dummies & Yes & Yes & Yes & Yes & Yes \\
\hline $\begin{array}{l}\text { Cohort Size, Unemployment, } \\
\text { Med. HH Income, Returns to BA }\end{array}$ & Yes & Yes & Yes & Yes & Yes \\
\hline Strong Merit States & Treatment & Treatment & Treatment & Treatment & Treatment \\
\hline Weak Merit States & Excluded & Treatment & Control & Excluded & Treatment \\
\hline Non-Merit States & Control & Control & Control & Excluded & Excluded \\
\hline Total States & 35 & 51 & 51 & 9 & 25 \\
\hline Ages Included & $24-30$ & $24-30$ & $24-30$ & $\begin{array}{l}24-30 \\
2000-\end{array}$ & $24-30$ \\
\hline Years Included & $2000-2010$ & $2000-2010$ & $2000-2010$ & 2010 & $2000-2010$ \\
\hline
\end{tabular}

Notes: Standard errors in parentheses are clustered by state of birth. Conley-Taber $95 \%$ confidence intervals are in brackets; these are not computed for columns 4 and 5 because there are no states included that did not implement a policy change. *Significant at $10 \%$ based on standard errors clustered by state of birth. 
Table 5: Merit Program Effects Accounting for Measurement Error in Treatment Status

(1)

Excluding "Marginal"

Birth Cohorts

A. Any College

B. Associate's Degree or Higher

C. Bachelor's Degree or Higher

$-0.0032$

(0.0058)

$[-0.01160 .0156]$

$-0.0054$

(0.0043)

$\left[\begin{array}{ll}-0.0120 & 0.0141]\end{array}\right]$

-0.0067
$(0.0037)^{*}$
$[-0.01760 .0082]$

Yes

Yes

Yes

Yes

Yes

Strong Merit States

Weak Merit States

Non-Merit States

Ages Included

Years Included

Treatment

Excluded

Control

24-30

2000-2010
(2)

Using Probability of Living in Birth State

$-0.0025$

(0.0058)

$\left[\begin{array}{ll}-0.0112 & 0.0166\end{array}\right]$

$-0.0031$

(0.0035)

[-0.0100 0.0140$]$

$-0.0056$

(0.0045)

[-0.0171 0.0109$]$

Yes

Yes

Yes

Yes

Yes

Treatment

Excluded

Control

24-30

2000-2010
(3)

Accounting for Both

$-0.0028$

(0.0075)

$\left[\begin{array}{ll}-0.0129 & 0.0211\end{array}\right]$

$-0.0065$

(0.0056)

[-0.0150 0.0187$]$

$-0.0082$

(0.0049)

$\left[\begin{array}{ll}-0.0213 & 0.0109\end{array}\right]$

Yes

Yes

Yes

Yes

Yes

Treatment

Excluded

Control

24-30

2000-2010

Notes: Standard errors in parentheses are clustered by state of birth. Conley-Taber $95 \%$ confidence intervals are in brackets. Column (1) excludes from the sample persons who were age 18 in the year of or year before the merit program was implemented in their birth state. Column (2) measures merit exposure by the predicted probability of going to high school in a merit state based on state of birth. See text for further details.

*Significant at $10 \%$ based on standard errors clustered by state of birth. 
Table 6: Merit Program Effects by Sex and Race/Ethnicity

\begin{tabular}{|c|c|c|c|c|}
\hline & $\begin{array}{c}\text { (1) } \\
\text { White } \\
\text { Non-Hispanic } \\
\text { Men } \\
\end{array}$ & $\begin{array}{c}\text { (2) } \\
\text { White } \\
\text { Non-Hispanic } \\
\text { Women }\end{array}$ & $\begin{array}{c}(3) \\
\text { Non-White } \\
\text { or Hispanic } \\
\text { Men }\end{array}$ & $\begin{array}{c}\text { (4) } \\
\text { Non-White } \\
\text { or Hispanic } \\
\text { Women } \\
\end{array}$ \\
\hline A. Any College & 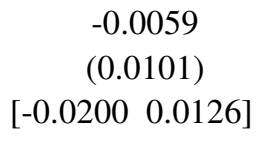 & $\begin{array}{c}0.0066 \\
(0.0061) \\
{[-0.00480 .0279]}\end{array}$ & $\begin{array}{c}-0.0199 \\
(0.0063)^{* * *} \\
{[-0.05480 .0261]}\end{array}$ & $\begin{array}{c}-0.0097 \\
(0.0067) \\
{[-0.0387 \quad 0.0534]}\end{array}$ \\
\hline B. Associate's Degree or Higher & $\begin{array}{c}-0.0021 \\
(0.0066) \\
{[-0.01220 .0204]}\end{array}$ & $\begin{array}{c}-0.0100 \\
(0.0052)^{*} \\
{[-0.02390 .0105]}\end{array}$ & $\begin{array}{c}0.0066 \\
(0.0087) \\
{[-0.02020 .0359]}\end{array}$ & $\begin{array}{c}-0.0045 \\
(0.0071) \\
{[-0.03380 .0299]}\end{array}$ \\
\hline C. Bachelor's Degree or Higher & $\begin{array}{c}-0.0084 \\
(0.0056) \\
{[-0.02290 .0170]}\end{array}$ & $\begin{array}{c}-0.0085 \\
(0.0048)^{*} \\
{[-0.02420 .0101]}\end{array}$ & $\begin{array}{c}-0.0040 \\
(0.0086) \\
{[-0.01880 .0301]}\end{array}$ & $\begin{array}{c}0.0023 \\
(0.0048) \\
{[-0.0306 \quad 0.0412]}\end{array}$ \\
\hline State of Birth Dummies & Yes & Yes & Yes & Yes \\
\hline Year of Birth Dummies & Yes & Yes & Yes & Yes \\
\hline Age Dummies & Yes & Yes & Yes & Yes \\
\hline Race and Ethnicity Dummies & N/A & N/A & Yes & Yes \\
\hline $\begin{array}{l}\text { Cohort Size, Unemployment, } \\
\text { Med. HH Income, Returns to BA }\end{array}$ & Yes & Yes & Yes & Yes \\
\hline Strong Merit States & Treatment & Treatment & Treatment & Treatment \\
\hline Weak Merit States & Excluded & Excluded & Excluded & Excluded \\
\hline Non-Merit States & Control & Control & Control & Control \\
\hline Ages Included & $24-30$ & $24-30$ & $24-30$ & $24-30$ \\
\hline Years Included & $2000-2010$ & $2000-2010$ & $2000-2010$ & $2000-2010$ \\
\hline
\end{tabular}

Notes: Standard errors in parentheses are clustered by state of birth. Conley-Taber $95 \%$ confidence intervals are in brackets.

*Significant at $10 \%$ based on standard errors clustered by state of birth; ***Significant at $1 \%$. 
Table 7: Merit Program Effects by Age

\begin{tabular}{|c|c|c|c|}
\hline & Any College & Associate's Degree + & Bachelor's Degree + \\
\hline \multirow[t]{3}{*}{ Age 22} & -0.0137 & -0.0182 & -0.0094 \\
\hline & $(0.0088)$ & $(0.0107)^{*}$ & $(0.0062)$ \\
\hline & {$\left[\begin{array}{ll}-0.0317 & 0.0222\end{array}\right]$} & {$\left[\begin{array}{lll}-0.0378 & -0.0011\end{array}\right]$} & {$\left[\begin{array}{ll}-0.0207 & 0.0122\end{array}\right]$} \\
\hline \multirow[t]{3}{*}{ Age 23} & 0.002 & 0.0095 & -0.0032 \\
\hline & $(0.0120)$ & $(0.0088)$ & $(0.0103)$ \\
\hline & {$\left[\begin{array}{ll}-0.0290 & 0.0397\end{array}\right]$} & {$\left[\begin{array}{ll}-0.0194 & 0.0430\end{array}\right]$} & {$\left[\begin{array}{ll}-0.0273 & 0.0171\end{array}\right]$} \\
\hline \multirow[t]{3}{*}{ Age 24} & 0.0073 & 0.0182 & 0.0012 \\
\hline & $(0.0153)$ & $(0.0117)$ & $(0.0111)$ \\
\hline & {$\left[\begin{array}{ll}-0.0150 & 0.0402\end{array}\right]$} & {$\left[\begin{array}{ll}0.0037 & 0.0454\end{array}\right]$} & {$\left[\begin{array}{ll}-0.0135 & 0.0288\end{array}\right]$} \\
\hline \multirow[t]{3}{*}{ Age 25} & -0.0121 & -0.003 & -0.0165 \\
\hline & $(0.0094)$ & $(0.0080)$ & $(0.0101)$ \\
\hline & {$\left[\begin{array}{ll}-0.0311 & 0.0251\end{array}\right]$} & {$\left[\begin{array}{ll}-0.0215 & 0.0279\end{array}\right]$} & {$\left[\begin{array}{ll}-0.0319 & 0.0040\end{array}\right]$} \\
\hline \multirow[t]{3}{*}{ Age 26} & -0.0291 & -0.0079 & -0.0169 \\
\hline & $(0.0067)^{* * *}$ & $(0.0071)$ & $(0.0057)^{* * *}$ \\
\hline & {$\left[\begin{array}{ll}-0.0501 & -0.0023\end{array}\right]$} & {$\left[\begin{array}{ll}-0.0264 & 0.0188\end{array}\right]$} & {$\left[\begin{array}{ll}-0.0339 & 0.0136\end{array}\right]$} \\
\hline \multirow[t]{3}{*}{ Age 27} & -0.0021 & -0.014 & -0.0145 \\
\hline & $(0.0098)$ & $(0.0051)^{* *}$ & $(0.0038) * * *$ \\
\hline & {$\left[\begin{array}{ll}-0.0214 & 0.0364\end{array}\right]$} & {$\left[\begin{array}{ll}-0.0264 & 0.0215\end{array}\right]$} & {$\left[\begin{array}{ll}-0.0290 & 0.0141\end{array}\right]$} \\
\hline \multirow[t]{3}{*}{ Age 28} & -0.0009 & 0.004 & 0.0074 \\
\hline & $(0.0122)$ & $(0.0124)$ & $(0.0097)$ \\
\hline & {$\left[\begin{array}{ll}-0.0374 & 0.0243\end{array}\right]$} & {$\left[\begin{array}{ll}-0.0345 & 0.0388\end{array}\right]$} & {$\left[\begin{array}{ll}-0.0206 & 0.0398\end{array}\right]$} \\
\hline \multirow[t]{3}{*}{ Age 29} & -0.0041 & -0.0148 & -0.0127 \\
\hline & $(0.0068)$ & $(0.0104)$ & $(0.0102)$ \\
\hline & {$\left[\begin{array}{ll}-0.0285 & 0.0364\end{array}\right]$} & {$\left[\begin{array}{ll}-0.0348 & 0.0226\end{array}\right]$} & {$\left[\begin{array}{ll}-0.0366 & 0.0200\end{array}\right]$} \\
\hline \multirow[t]{3}{*}{ Age 30} & 0.0241 & 0.0092 & 0.0193 \\
\hline & $(0.0108)^{* *}$ & $(0.0165)$ & $(0.0149)$ \\
\hline & {$\left[\begin{array}{ll}-0.0072 & 0.0616\end{array}\right]$} & {$\left[\begin{array}{ll}-0.0232 & 0.0411]\end{array}\right.$} & {$\left[\begin{array}{ll}-0.0204 & 0.0437\end{array}\right]$} \\
\hline \multirow[t]{3}{*}{ Age 31} & -0.0133 & -0.0067 & -0.0028 \\
\hline & $(0.0136)$ & $(0.0151)$ & $(0.0083)$ \\
\hline & {$\left[\begin{array}{ll}-0.0768 & 0.0347\end{array}\right]$} & {$\left[\begin{array}{ll}-0.0692 & 0.0409\end{array}\right]$} & {$\left[\begin{array}{ll}-0.0511 & 0.0369\end{array}\right]$} \\
\hline
\end{tabular}

Notes: Regressions include dummies for state of birth, year of birth, age, sex, race, and ethnicity and the additional state controls. Weak merit states are excluded from the analysis. Standard errors in parentheses are clustered by state of birth. Conley-Taber $95 \%$ confidence intervals are in brackets.

*Significant at $10 \%$ based on standard errors clustered by state of birth; **Significant at 5\%; ***Significant at $1 \%$. 
Table 8: Merit Effects by State of Birth

\begin{tabular}{|c|c|c|c|}
\hline & Any College & Associate's Degree + & Bachelor's Degree + \\
\hline \multirow[t]{2}{*}{ Alaska } & -0.0281 & -0.0060 & 0.0095 \\
\hline & {$\left[\begin{array}{ll}-0.0497 & -0.0050]\end{array}\right.$} & {$\left[\begin{array}{ll}-0.0228 & 0.0109\end{array}\right]$} & {$\left[\begin{array}{ll}-0.0079 & 0.0389\end{array}\right]$} \\
\hline \multirow[t]{2}{*}{ Arkansas } & -0.0162 & -0.0098 & 0.0051 \\
\hline & {$\left[\begin{array}{ll}-0.0852 & 0.0181\end{array}\right]$} & {$\left[\begin{array}{ll}-0.0406 & 0.0201\end{array}\right]$} & {$\left[\begin{array}{ll}-0.0728 & 0.0365\end{array}\right]$} \\
\hline \multirow[t]{2}{*}{ California } & 0.0019 & -0.0088 & -0.0143 \\
\hline & {$\left[\begin{array}{lll}-0.0314 & 0.0305\end{array}\right]$} & {$\left[\begin{array}{ll}-0.0330 & 0.0241]\end{array}\right.$} & {$\left[\begin{array}{ll}-0.0416 & 0.0299\end{array}\right]$} \\
\hline \multirow[t]{2}{*}{ Florida } & -0.0105 & -0.0074 & -0.0109 \\
\hline & {$\left[\begin{array}{ll}-0.0282 & 0.0172\end{array}\right]$} & {$\left[\begin{array}{ll}-0.0196 & 0.0271\end{array}\right]$} & {$\left[\begin{array}{ll}-0.0341 & 0.0240\end{array}\right]$} \\
\hline \multirow[t]{2}{*}{ Georgia } & 0.0089 & 0.0030 & 0.0135 \\
\hline & {$\left[\begin{array}{ll}-0.0468 & 0.0331\end{array}\right]$} & {$\left[\begin{array}{ll}-0.0224 & 0.0359\end{array}\right]$} & {$\left[\begin{array}{ll}-0.0446 & 0.0400\end{array}\right]$} \\
\hline \multirow[t]{2}{*}{ Idaho } & -0.0057 & -0.0434 & -0.0325 \\
\hline & {$\left[\begin{array}{ll}-0.0355 & 0.0234\end{array}\right]$} & {$\left[\begin{array}{ll}-0.0684 & -0.012\end{array}\right]$} & {$\left[\begin{array}{lll}-0.0578 & 0.0112\end{array}\right]$} \\
\hline \multirow[t]{2}{*}{ Illinois } & 0.0048 & 0.0089 & 0.0056 \\
\hline & {$\left[\begin{array}{ll}-0.0185 & 0.0260\end{array}\right]$} & {$\left[\begin{array}{ll}-0.0055 & 0.0281\end{array}\right]$} & {$\left[\begin{array}{ll}-0.0106 & 0.0368\end{array}\right]$} \\
\hline \multirow[t]{2}{*}{ Kentucky } & 0.0147 & 0.0047 & -0.0090 \\
\hline & {$\left[\begin{array}{ll}-0.0075 & 0.0378\end{array}\right]$} & {$\left[\begin{array}{ll}-0.0092 & 0.0245\end{array}\right]$} & {$\left[\begin{array}{ll}-0.0251 & 0.0218\end{array}\right]$} \\
\hline \multirow[t]{2}{*}{ Louisiana } & 0.0012 & -0.0012 & -0.0021 \\
\hline & {$\left[\begin{array}{ll}-0.0296 & 0.0286\end{array}\right]$} & {$\left[\begin{array}{ll}-0.0181 & 0.0234\end{array}\right]$} & {$\left[\begin{array}{ll}-0.0234 & 0.0236\end{array}\right]$} \\
\hline \multirow[t]{2}{*}{ Maryland } & 0.0022 & 0.0256 & 0.0215 \\
\hline & {$\left[\begin{array}{ll}-0.0487 & 0.0423\end{array}\right]$} & {$\left[\begin{array}{ll}-0.0108 & 0.0701\end{array}\right]$} & {$\left[\begin{array}{ll}-0.0096 & 0.0752\end{array}\right]$} \\
\hline \multirow[t]{2}{*}{ Michigan } & -0.0077 & 0.0059 & 0.0042 \\
\hline & {$\left[\begin{array}{ll}-0.0347 & 0.0152\end{array}\right]$} & {$\left[\begin{array}{ll}-0.0244 & 0.0260\end{array}\right]$} & {$\left[\begin{array}{ll}-0.0396 & 0.0389\end{array}\right]$} \\
\hline \multirow[t]{2}{*}{ Mississippi } & -0.0051 & 0.0031 & -0.0100 \\
\hline & {$\left[\begin{array}{ll}-0.0168 & 0.0326\end{array}\right]$} & {$\left[\begin{array}{ll}-0.0204 & 0.0559\end{array}\right]$} & {$\left[\begin{array}{ll}-0.0333 & 0.0273\end{array}\right]$} \\
\hline \multirow[t]{2}{*}{ Missouri } & -0.0080 & -0.0080 & -0.0150 \\
\hline & {$\left[\begin{array}{ll}-0.0248 & 0.0205\end{array}\right]$} & {$\left[\begin{array}{ll}-0.0204 & 0.0263\end{array}\right]$} & {$\left[\begin{array}{lll}-0.0394 & 0.0190\end{array}\right]$} \\
\hline \multirow[t]{2}{*}{ Nevada } & -0.0093 & 0.0064 & -0.0038 \\
\hline & {$\left[\begin{array}{lll}-0.0356 & 0.0136\end{array}\right]$} & {$\left[\begin{array}{ll}-0.0309 & 0.0200\end{array}\right]$} & {$\left[\begin{array}{ll}-0.0534 & 0.0242\end{array}\right]$} \\
\hline \multirow[t]{2}{*}{ New Jersey } & 0.0004 & 0.0074 & 0.0007 \\
\hline & {$\left[\begin{array}{ll}-0.0178 & 0.0277\end{array}\right]$} & {$\left[\begin{array}{ll}-0.0069 & 0.0399\end{array}\right]$} & {$\left[\begin{array}{ll}-0.0252 & 0.0339\end{array}\right]$} \\
\hline \multirow[t]{2}{*}{ New Mexico } & -0.0146 & -0.0126 & -0.0076 \\
\hline & {$\left[\begin{array}{ll}-0.0178 & 0.0277\end{array}\right]$} & {$\left[\begin{array}{ll}-0.0278 & 0.0187\end{array}\right]$} & {$\left[\begin{array}{ll}-0.0330 & 0.0253\end{array}\right]$} \\
\hline \multirow[t]{2}{*}{ New York } & -0.0087 & 0.0026 & -0.0020 \\
\hline & {$\left[\begin{array}{ll}-0.0251 & 0.0199\end{array}\right]$} & {$\left[\begin{array}{ll}-0.0113 & 0.0367\end{array}\right]$} & {$\left[\begin{array}{ll}-0.0262 & 0.0327\end{array}\right]$} \\
\hline \multirow[t]{2}{*}{ North Dakota } & -0.0095 & 0.0165 & 0.0059 \\
\hline & {$\left[\begin{array}{ll}-0.0255 & 0.0119\end{array}\right]$} & {$\left[\begin{array}{ll}-0.0073 & 0.0511\end{array}\right]$} & {$\left[\begin{array}{ll}-0.0203 & 0.0474\end{array}\right]$} \\
\hline \multirow[t]{2}{*}{ Oklahoma } & 0.0025 & 0.0044 & -0.0041 \\
\hline & {$\left[\begin{array}{ll}-0.0115 & 0.0386\end{array}\right]$} & {$\left[\begin{array}{ll}-0.0178 & 0.0590\end{array}\right]$} & {$\left[\begin{array}{ll}-0.0273 & 0.0330\end{array}\right]$} \\
\hline \multirow[t]{2}{*}{ South Carolina } & -0.0053 & -0.0106 & -0.0109 \\
\hline & {$\left[\begin{array}{ll}-0.0341 & 0.0239\end{array}\right]$} & {$\left[\begin{array}{ll}-0.0264 & 0.0148\end{array}\right]$} & {$\left[\begin{array}{ll}-0.0309 & 0.0146\end{array}\right]$} \\
\hline \multirow[t]{2}{*}{ South Dakota } & -0.0254 & 0.0494 & 0.0213 \\
\hline & {$\left[\begin{array}{lll}-0.1724 & 0.0308\end{array}\right]$} & {$\left[\begin{array}{ll}-0.0242 & 0.1399\end{array}\right]$} & {$[-0.03500 .1166]$} \\
\hline \multirow[t]{2}{*}{ Tennessee } & -0.0002 & -0.0042 & -0.0015 \\
\hline & {$\left[\begin{array}{ll}-0.0855 & 0.0428\end{array}\right]$} & {$\left[\begin{array}{ll}-0.0393 & 0.0448\end{array}\right]$} & {$\left[\begin{array}{ll}-0.0409 & 0.0756\end{array}\right]$} \\
\hline Utah & -0.0120 & -0.0325 & -0.0255 \\
\hline & {$\left[\begin{array}{ll}-0.0366 & 0.0088\end{array}\right]$} & {$\left[\begin{array}{ll}-0.0485 & -0.0148\end{array}\right]$} & {$\left[\begin{array}{ll}-0.0432 & 0.0039\end{array}\right]$} \\
\hline Washington & -0.0228 & -0.0244 & -0.0202 \\
\hline & {$\left[\begin{array}{ll}-0.0450 & -0.0001]\end{array}\right.$} & {$\left[\begin{array}{ll}-0.0387 & -0.0050]\end{array}\right.$} & {$\left[\begin{array}{ll}-0.0378 & 0.0092\end{array}\right]$} \\
\hline West Virginia & 0.0017 & 0.0303 & 0.0235 \\
\hline & {$\left[\begin{array}{ll}-0.0462 & 0.0461]\end{array}\right.$} & {$\left[\begin{array}{ll}-0.0037 & 0.0778\end{array}\right]$} & {$\left[\begin{array}{ll}-0.0076 & 0.0797\end{array}\right]$} \\
\hline
\end{tabular}

Notes: Regressions include dummies for state of birth, year of birth, age, sex, race, and ethnicity and the additional state controls. Conley-Taber $90 \%$ confidence intervals are in brackets. 
Table 9: Effects of Post-HOPE Dummy on Degree Completion in the USG

\begin{tabular}{|c|c|c|c|c|}
\hline & (1) & (2) & (3) & (4) \\
\hline \multicolumn{5}{|l|}{ A. Associate's or Bachelor's Degree } \\
\hline \multirow[t]{2}{*}{ By Four Years After High School } & 0.0047 & 0.0102 & -0.0093 & -0.0388 \\
\hline & $(0.0048)$ & $(0.0034)^{*}$ & $(0.0042)$ & $(0.0040)^{* * *}$ \\
\hline \multirow[t]{2}{*}{ By Five Years After High School } & 0.0079 & 0.0127 & -0.0085 & -0.0421 \\
\hline & $(0.0054)$ & $(0.0037)^{* *}$ & $(0.0053)$ & $(0.0055)^{* * *}$ \\
\hline \multirow[t]{2}{*}{ By Six Years After High School } & 0.0081 & 0.0126 & -0.0087 & -0.0426 \\
\hline & $(0.0061)$ & $(0.0052)^{*}$ & $(0.0060)$ & $(0.0049)^{* * *}$ \\
\hline \multirow[t]{2}{*}{ By Twelve Years After High School } & 0.0137 & 0.0180 & -0.0033 & -0.0349 \\
\hline & $(0.0055)^{*}$ & $(0.0046)^{* *}$ & $(0.0058)$ & $(0.0054) * * *$ \\
\hline \multicolumn{5}{|l|}{ B. Bachelor's Degree } \\
\hline \multirow[t]{2}{*}{ By Four Years After High School } & 0.0168 & 0.0197 & -0.0005 & -0.0269 \\
\hline & $(0.0052)^{* *}$ & $(0.0030)^{* * *}$ & $(0.0042)$ & $(0.0044)^{* * *}$ \\
\hline \multirow[t]{2}{*}{ By Five Years After High School } & 0.0207 & 0.0231 & 0.0012 & -0.0300 \\
\hline & $(0.0061)^{* *}$ & $(0.0038) * * *$ & $(0.0059)$ & $(0.0064) * *$ \\
\hline \multirow[t]{2}{*}{ By Six Years After High School } & 0.0212 & 0.0236 & 0.0015 & -0.0303 \\
\hline & $(0.0062) * *$ & $(0.0048) * *$ & $(0.0059)$ & $(0.0052) * *$ \\
\hline \multirow[t]{2}{*}{ By Twelve Years After High School } & 0.0258 & 0.0280 & 0.0057 & -0.0243 \\
\hline & $(0.0068)^{* *}$ & $(0.0053)^{* *}$ & $(0.0067)$ & $(0.0062)^{* *}$ \\
\hline Sex, Race, Ethnicity Dummies & No & Yes & Yes & Yes \\
\hline High School Dummies & No & Yes & Yes & Yes \\
\hline SAT Dummies & No & No & Yes & Yes \\
\hline High School GPA Dummies & No & No & No & Yes \\
\hline
\end{tabular}

Notes: Regressions include 93,407 total observations for four cohorts of recent high school graduate first time freshmen. Standard errors in parentheses are clustered by high school graduation year.

*Significant at $10 \%$ based on small sample t-distribution; **Significant at 5\%; ***Significant at $1 \%$. 